
\title{
25 Research Square \\ Effects of Nitric Oxide On The Growth of The Marine Microalgae And The Parameters of Carbonate Chemistry
}

\section{Li Peifeng}

Ocean University of China

\section{Zhao Min}

Ocean University of China

Liu Chunying ( $\nabla$ roseliu@ouc.edu.cn )

Ocean University of China - Laoshan Campus: Ocean University of China

\section{Yang Guipeng}

Ocean University of China

\section{Research Article}

Keywords: Marine microalgae, Nitric oxide (NO), Growth, Carbonate system, Dual role, Photosynthesis

Posted Date: May 20th, 2021

DOI: https://doi.org/10.21203/rs.3.rs-521371/v1

License: (c) (i) This work is licensed under a Creative Commons Attribution 4.0 International License. Read Full License 


\section{Abstract}

Nitric oxide (NO) is a non-traditional regulator for the growth of plant and phytoplankton. This study monitored the growth of five marine phytoplankton species, namely, Platymonas helgolandica var. tsingtaoensis, Platymonas subcordiformis, Skeletonema costatum, Gymnodinium sp., and Prorocentrum donghaiense, and examined the parameters of the carbonate system in the culture media after adding different concentrations of NO and sodium nitroprusside (SNP, NO donor) solutions. The different concentrations of exogenous NO had various roles in the growth of these microalgae. The two food algae,namely, $P$. helgolandica var. tsingtaoensis, $P$. subcordiformis, and three red tide algae, namely $S$. costatum, Gymnodinium sp., and $P$. donghaiense showed different responses to the same NO concentration. The red tide algae were more sensitive to exogenous NO than the food algae. NO with the concentration of $1.4 \times 10^{-6} \mathrm{~mol} \mathrm{~L}^{-1}$ had the optimum stimulatory effect on the growth of the microalgae, the cell density increased by $9.8 \sim 38.3 \%$. SNP solution with the concentration of $100 \mu \mathrm{mol} \mathrm{L}^{-1}$ inhibited the growth of the two food algae, the cell density decreased by $38.8 \sim 84.3 \%$. Meanwhile, $10 \mu \mathrm{mol} \mathrm{L}-1$ SNP solution additions to the three red tide algae declined the cell density by $95.3 \sim 99.9 \%$. Low concentrations of SNP $\left(0.1 \mu \mathrm{mol} \mathrm{L}-1\right.$ for the two food algae and $0.01 \mu \mathrm{mol} \mathrm{L}^{-1}$ for the red tide algae $)$ promoted the growth of microalgae slightly. Different concentrations of exogenous NO could also influence parameters of the carbonate system in the culture media. NO participates in the regulation of marine microalgae photosynthesis, which may influence the parameters of carbonate system.

\section{Introduction}

Nitric oxide (NO) is an important signaling molecule that regulates a wide range of physiological, cytological, and molecular processes in animals and plants (Wendehenne et al. 2001; Li and Moore, 2007; Lushchak 2011; Domingos et al. 2015). In comparison with animals and plants, the knowledge about NO in the marine systems is still limited. NO is an important intermediate in the marine nitrogen cycle. The sources of NO in seawater are mainly involved in photochemistry (Zafiriou and True 1979; Olasehinde et al. 2009) and biological activity (Lipton et al. 1993; Martens-Habbena et al. 2014). Sunlight photolyzes $\mathrm{NO}_{2}{ }^{-}$in surface seawater and generates a low concentration of NO. The concentration of NO in the surface seawater was about $10^{-12}$ to $10^{-10} \mathrm{~mol} \mathrm{~L}^{-1}$ (Zafiriou and McFarland 1981; Olasehinde et al. 2009; 2010; Anifowose and Sakugawa 2017; Tian et al. 2020), moreover, NO showed higher concentration levels in coastal waters than in open sea (Tian et al. 2020).

Previous research focused on the production of $\mathrm{NO}$ and its physiological functions of NO on marine phytoplankton. Several reports have suggested that algae and cyanobacteria could produce NO (Mallick et al. 1999, 2000; Sakihama et al. 2002; Tischner et al. 2004). We also detected NO concentrations in the culture media of several species of marine microalgae during their growth. NO with the concentrations of $10^{-9}-10^{-8} \mathrm{~mol} \mathrm{~L}^{-1}$ was observed in the algal culture pond of Daya Bay $\left(1-300 \mathrm{~m}^{3}\right)$ before the algal density reached its maximum, revealing the possible relationship between the NO concentration and algal bloom (Zhang et al. 2006c). The $\mathrm{NO}_{3}{ }^{-}$reductase (NR) pathway and a NO synthesis enzyme might be 
responsible for the NO generation of algae (Kim et al. 2006, 2008; Tang et al. 2011). Sakihama et al. (2002) reported that $\mathrm{NR}$ is involved in the $\mathrm{NO}_{2}{ }^{-}$-dependent $\mathrm{NO}$ production in $\mathrm{C}$. reinhardtii. Tischner et al. (2004) concluded that mitochondria can produce $\mathrm{NO}$ under anoxia and sufficient $\mathrm{NO}_{2}{ }^{-}$supply in $\mathrm{C}$. sorokiniana. However, the NO production mechanism in microalgae and cyanobacteria is still unclear.

Microalgae and cyanobacteria can not only generate endogenous NO, but also respond to exogenous NO. It has been documented that $\mathrm{NO}$ can control the growth of microalgae depending on the local concentration of NO (Leshem et al. 1998; Zhang et al. 2005, 2006b; Lehner et al. 2009; Misra et al. 2014). Tang et al. (2011) pointed out the promotion effect of NO on the growth of $M$. aerugrinosa and the correlation of $\mathrm{NO}$ with the outbreak of cyanobacterial bloom was revealed to some extent. NO is an indicator of microalga growth and a signal molecule of the stress response (Zhang et al. 2006a, 2006b, 2006c). Previous studies showed that NO was involved in the protective effects under abiotic and biotic toxicity stresses including copper ion, sodium selenium, lead nitrate, methomyl, and ultraviolet (UV) radiation stress in marine algae (Mackerness et al. 2001; Mittler et al. 2004; Chen et al. 2003; Singh et al. 2004; Liu et al. 2008; Feng et al. 2011; Xiao et al. 2012; Li et al. 2013; Misra et al. 2014). Moreover, the function and role of NO in marine ecosystem requires more research and exploration.

Direct addition of NO and NO donors were used to investigate the effects of NO on the microalgae. NO is a short life bioactive molecule with the half-life ranging from 5 to $13 \mathrm{~s}$ (Gupta et al. 2011), however, it is relatively stable at very low concentration in seawater and plants (Zafiriou and Mcfarland 1981; Planchet et al. 2005). NO is a signaling molecule with high diffusion rate and high reactivity. As a free radical molecule, NO diffuses readily through biological membranes and reacts with metal complexes, radicals, and biomolecules such as nucleic acids, proteins and lipids (Wink and Mitchell 1998). NO donors are compounds which can continuously release NO when applied to biological systems to mimic endogenous NO-related responses. Sodium nitroprusside (SNP) is the most commonly used NO donor with the half-life of $12 \mathrm{~h}$ (Floryszak-Wieczorek et al. 2006).

The oceanic carbonate system, closely related to the photosynthetic process of phytoplankton, is important in many branches of marine chemistry and biology (Wilhelm et al. 2006; Chi et al. 2011). Exploring the factors that influence marine phytoplankton photosynthesis is important to the study of the global carbon cycle. Hill and Bennett (1970) reported that carbon dioxide $\left(\mathrm{CO}_{2}\right)$ assimilation rates are inhibited by the increased NO gas for the fumigation of trees. Yamasaki (2000) demonstrated that excessive $\mathrm{NO}$ directly inhibits $\mathrm{CO}_{2}$ assimilation and electron flow in the mitochondrial inner membrane of photosynthesizing organisms. Despite the recognized importance of the role of marine phytoplankton in the global carbon cycle, which yield approximately $50 \%$ of the total global primary productivity, few studies have investigated the influence of $\mathrm{NO}$ on the carbonate system in seawater.

This study investigated the modulating function of NO on the growth of five marine phytoplankton species, namely, Platymonas helgolandica var. tsingtaoensis, P. subcordiformis, S. costatum, Gymnodinium sp., and Prorocentrum donghaiense, and corresponding variations of parameters of $\mathrm{CO}_{2}$ system in the S. costatum culture media after adding different concentrations of SNP. Marine green algae 
$P$. helgolandica var. tsingtaoensis and $P$. subcordiformis are widely used as high-quality plant baits for seafood larvae. The red tide species $S$. costatum, Gymnodinium sp., and $P$. donghaiense frequently cause blooms in the East China Sea in early summer. The present research sheds light on the effect of NO on the growth of the marine algae and the parameters of carbonate system.

\section{Materials And Methods}

\section{Algal cultivation}

The strains of $P$. helgolandica var.tsingtaoensis, P. subcordiformis, S. costatum, Gymnodinium sp., and $P$. donghaiense were obtained from the Marine Pollution Eco-Chemistry Laboratory, the Ocean University of China, Qingdao. The seawater used in the experiment was collected from the East China Sea, then sterilized in a LDZX-II Autoclaves Sterilizer (Shanghai Shenan Medical Instrument Factory, China) for 20 min after being filtrated through a cellulose acetate filter $(0.45 \mu \mathrm{m})$. All the bottles were treated by the following procedure: first soaked in hydrochloric acid for 24 hours, then washed with ultra-pure water, and finally sterilized in a Autoclaves Sterilizer as seawater. All cultures were axenic and unialgal. The strain was inoculated by adding $100 \mathrm{~mL}$ of the stock culture media during the exponential growth phase to a $500 \mathrm{~mL}$ Erlenmeyer flask containing $300 \mathrm{~mL} f / 2$ medium (Guillard, 1975). No nutrients were added during the experiment. The media were initially adjusted to $\mathrm{pH} 8.100 \pm 0.001$ with $\mathrm{HCl}$. Each group had three replicates. All cultures were kept at $25.0 \pm 0.1^{\circ} \mathrm{C}$ in an illumination incubator (GXZ-380B, Ningbo Jiangnan Instrument Factory, Ningbo, China). The light condition was set as $14 \mathrm{~h}$ light and $10 \mathrm{~h}$ dark with an average photon flux density of $134 \mu \mathrm{mol} \mathrm{m}^{-2} \mathrm{~s}^{-1}$ (Liu et al. 2014b). The flasks with sterilized filter paper were shaken twice a day and randomly replaced on the shelves to avoid minor differences in irradiance exposure.

\section{Preparation of nitric oxide and sodium nitroprusside solutions}

Two milliliters of Milli-Q water sealed in a $10 \mathrm{~mL}$ vial was bubbled with high purity nitrogen gas $(99.999 \%$, Heli Industry Gas Center, Qingdao, China) at $10 \mathrm{~mL} \mathrm{~min}^{-1}$ (6 mm diameter tube) for at least $30 \mathrm{~min}$ to remove oxygen in the water. The deoxygenated water was then bubbled with high purity NO gas $(99.9 \%$, Date Gas Ltd, Dalian, China) for 30 min until reaching NO saturation with the concentration of about $1.4 \times$ $10^{-3} \mathrm{~mol} \mathrm{~L}^{-1}$ (Lantoine et al. 1995; Zhang et al. 2003). Standards were freshly made for each experiment, and different concentrations of NO solutions were obtained by diluting the saturated solution using MilliQ water (18.2 MW cm, Millipore Company, USA).

A total of $1.4790 \mathrm{~g}$ of sodium nitroprusside (SNP) (Sigma-Aldrich company, USA) was weighed accurately and poured into $100 \mathrm{~mL}$ of Milli-Q water that was subjected to high-pressure sterilization. A SNP stock solution of $50 \mathrm{mmol} \mathrm{L}^{-1}$ was obtained. Stock solutions were freshly made for each experiment.

\section{Experimental design}


The experimental cultures were exposed to different concentrations of NO or SNP solutions after inoculation. Some saturated or diluted NO solutions were added into the cultivation of five marine microalgae rapidly with a gas-tight syringe. The initial concentrations of $\mathrm{NO}$ in the culture media were 0 (the control), $1.4 \times 10^{-9}, 1.4 \times 10^{-8}, 1.4 \times 10^{-7}$, and $1.4 \times 10^{-6} \mathrm{~mol} \mathrm{~L}^{-1}$, respectively. Preliminary experiment results showed that the two food algae and the three red tide algae have different responses to the same concentration of SNP. Therefore, the initial concentrations of the SNP solutions in the cultures were set to $0,0.1,1.0,10$, and $100 \mu \mathrm{mol} \mathrm{L}^{-1}$ for the two food algae and $0,0.01,0.1,1.0$, and 10

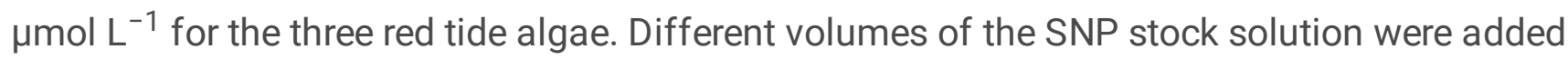
immediately into the culture media.

\section{Biological analysis}

An Olympus CX-31 microscope (Olympus Corporation, Tokyo, Japan) was used for Algal cells counting. An aliquot of $5 \mathrm{~mL}$ culture media was sampled and then preserved in Lugol's buffer solution. After that the cell were counted in triplicate by $1 \mathrm{~mL}$ Sedgwick-Rafter counting chambers (Liu et al. 2014a).

\section{Determination of carbonate system parameters in the culture media}

The $\mathrm{pH}$ value in the culture samples was analyzed using a Ross Orion combination electrode (Ross-8102) and a Fisher $\mathrm{pH}$ meter (AR15) on a NBS scale (precision: \pm 0.005$)$ under the cultivation temperature. The DIC was measured by a DIC analyzer (AS-C2, Apollo SciTech Inc., Georgia, USA) (Cai and Wang, 1998; Hu et al. 2015). An aliquot of a $0.5 \mathrm{~mL}$ sample was acidified by the addition of $10 \% \mathrm{H}_{3} \mathrm{PO}_{4}$ solution $(0.5 \mathrm{~mL})$. The extracted $\mathrm{CO}_{2}$ gas was then determined through a nondispersive infrared $\mathrm{CO}_{2}$ detector $(\mathrm{LI}-6262$, $\mathrm{Li}$ COR Inc., USA) with a precision of $0.1 \%-0.2 \%$. Certified reference materials from the A.G. Dickson of the Scripps Institution of Oceanography were used for calibration. The CO2SYS software (Pierrot et al. 2006) was used for calculating the concentrations of bicarbonate $\left(\mathrm{HCO}_{3}{ }^{-}\right)$and $p \mathrm{CO}_{2}$ from the values of $\mathrm{pH}$ and DIC. The equilibrium constants for calculation was from Mehrbach et al. (1973) refit by Dickson and Millero (1987) with $\mathrm{KHSO}_{4}$ from Dickson (1973) as described in the report by Hu et al. (2015). The precision of calculated $p \mathrm{CO}_{2}$ was $2.5 \mu$ atm (Grasshoff et al. 1999).

\section{Determination of NO concentration of the media}

The concentration of NO in the culture media was determined by an ISO-NO Mark II NO meter (WPI Inc., Sarasota, USA) connected with an ISO-NOPMC microsensor. A DU018 two-channel data-acquisition system (WPI Inc., Sarasota, USA) connected to a PC computer was used for the analog signal digitizing (Zhang et al. 2006c). The detection limit of the method was $4.2 \times 10^{-10} \mathrm{molL}^{-1}$. The experiment of precision showed that the relative standard deviation was $6.3 \%$ (Xing et al. 2005).

\section{Statistics}

Each group had three replicates. All data were expressed as mean \pm standard deviation. Statistical analysis was performed with origin 8.0 software (OriginLab Corp. Northampton, Massachusetts, USA). 
Comparison of two groups was performed via t-test. Mann Whitney Rank Sum test was used if datasets did not fulfill constraints of normal distribution and homogeneity of variance for t-test.

\section{Results}

\section{The variations of NO concentration in the $\mathrm{f} / 2$ medium and Gymnodinium sp. cultures after adding $1.4 \times$ $10^{-6} \mathrm{~mol} \mathrm{~L}^{-1}$ of $\mathrm{NO}$}

In order to understand the variations of NO when added into the culture media, we monitored the concentrations of NO after $1.4 \times 10^{-6} \mathrm{~mol} \mathrm{~L}^{-1}$ of NO was added into the $\mathrm{f} / 2$ medium and Gymnodinium sp. cultures (Fig. 1). Results showed that the concentration of NO decreased rapidly in both $\mathrm{f} / 2$ medium and Gymnodinium sp. culture medium. The concentrations of NO dropped to $10^{-8} \mathrm{~mol} \mathrm{~L}^{-1}$ in these two culture media after 2 hours, furthermore, it decreased more rapidly within 2 hours in the Gymnodinium sp. culture media, implying that microalgae might utilize exogenous NO. Then the concentrations of NO declined continually until it reaching $10^{-9} \mathrm{~mol} \mathrm{~L}^{-1}$ order of magnitude and were similar in both media. After 6 hours the concentrations of NO were higher in the Gymnodinium sp. culture media than those of

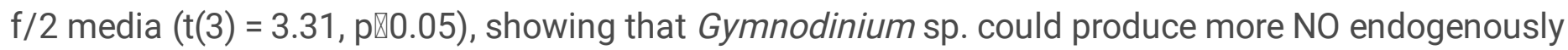
with the concentration of about $10^{-9} \mathrm{~mol} \mathrm{~L}^{-1}$. Moreover, the concentrations of $\mathrm{NO}$ in the Gymnodinium sp. culture media and $\mathrm{f} / 2$ media remained in the order of magnitude of $10^{-9} \mathrm{~mol} \mathrm{~L}^{-1}$. The magnitude of NO concentration was consistent with that observed in the natural environment with the range from $10^{-9}$ to $10^{-8} \mathrm{~mol} \mathrm{~L}^{-1}$ in the algal culture pond of Daya Bay (Zhang et al. 2006c).

\section{Effects of NO solutions on the growth of the marine microalgae}

Though the concentration of NO declined rapidly in the culture media, the effect of NO on the growth of microalgae was not only instantaneous. The addition of NO to the incubation culture only once even influenced the whole growth of the microalgae (Zhang et al. 2005). To avoid the instantaneous disturbances of NO, the exponential phase (Day 8) was chosen to investigate the effects of NO on the growth of microalgae. The cell densities of the five cultured microalgae on Day 8 were shown in Fig. 2. The algal growths in the case of $P$. helgolandica var. tsingtaoensis, $P$. subcordiformis, and $P$. donghaiense were promoted when different concentrations of NO were added during the cultivation. That is, $1.4 \times 10^{-6}$ $\mathrm{mol} \mathrm{L}^{-1}$ of NO had the optimum stimulatory effect on the growth of microalgae with an increase of $18.9 \%, 38.3 \%$, and $23.4 \%$ in cell density for $P$. helgolandica var. tsingtaoensis, $P$. subcordiformis, and $P$. donghaiense, respectively. Moreover, $1.4 \times 10^{-9}-1.4 \times 10^{-7} \mathrm{~mol} \mathrm{~L}^{-1}$ of NO solutions slightly promoted the growth of these three microalgae. The cell densities increased by $8.4-11.3 \%, 12.9-31.1 \%$, and $7.5-$ $15.0 \%$, respectively. The promotion was obvious when the concentration of NO solution was high. In $S$. costatum and Gymnodinium sp. culture media, $1.4 \times 10^{-6} \mathrm{~mol} \mathrm{~L}^{-1}$ of NO marked the increase in the growth of microalgae with cell density increases of $10.1 \%$ and $9.8 \%$, respectively. The other concentrations of NO showed minimal effect on the growth of these microalgae, and no significant difference was observed. 


\section{Effects of SNP solutions on the growth of the marine microalgae}

The cell densities of $P$. helgolandica var. tsingtaoensis, $P$. subcordiformis, S. costatum, Gymnodinium sp., and $P$. donghaiense on Day 8 are shown in Fig. 3. P. helgolandica var. tsingtaoensis and $P$. subcordiformis showed a significant decrease of $84.3 \%$ and $38.8 \%$ in cell density, respectively, after adding $100 \mu \mathrm{mol} \mathrm{L}-1$ of SNP solution compared with those of the control groups. The SNP with $0.1 \mu \mathrm{molL}^{-1}$ concentration had little effect on the growth of $P$. helgolandica var. tsingtaoensis. However, $10.8 \%$ and $13.1 \%$ increases were observed when 1.0 and $10 \mu \mathrm{mol} \mathrm{L}-1$ SNP solutions were added, respectively. When the SNP concentrations were $0.1,1.0$, and $10 \mu \mathrm{mol} \mathrm{L}^{-1}$, the growth of $P$. subcordiformis was promoted and the cell densities increased by $8.3 \%, 10.8 \%$, and $14.3 \%$, respectively.

For the three red tide algae, namely $S$. costatum, Gymnodinium sp., and $P$. donghaiense, SNP with the concentration of $10 \mu \mathrm{mol} \mathrm{L}{ }^{-1}$ strongly inhibited the growth of microalgae. The decreases in cell densities were $95.3 \%, 99.9 \%$, and $97.5 \%$, respectively, which indicated that no exponential growth was observed during cultivation. A slight decrease in final cell density compared to the control was observed in the $S$. costatum culture at $1.0 \mu \mathrm{mol} \mathrm{L}^{-1}$ of SNP. However, a slight increase was observed when the culture media was supplemented with $0.1 \mu \mathrm{mol} \mathrm{L}-1$ of SNP. The SNP concentration of $0.01 \mu \mathrm{mol} \mathrm{L^{-1 }}$ presented little influence on the growth of $S$. costatum. A similar phenomenon was observed in the culture of $P$. donghaiense after adding different concentrations of SNP solutions. An obvious decline in the cell density of Gymnodinium sp. was observed, except when $0.01 \mu \mathrm{mol} \mathrm{L^{-1 }}$ of SNP was added. The decreases were $26.7 \%$ and $84.3 \%$ for 0.1 and $1 \mu \mathrm{mol} \mathrm{L}-1$ of SNP, respectively.

\section{Effects of SNP solutions on the parameters of the carbonate chemistry}

The variations of the $\mathrm{CO}_{2}$ parameters in the culture media of $S$. costatum on Day 8 are shown in Table 1. The values of $\mathrm{HCO}_{3}{ }^{-}, \mathrm{CO}_{3}{ }^{2-}, \mathrm{pCO}_{2}, \mathrm{CO}_{2}$, and TA were calculated from $\mathrm{pH}$ and DIC. The initial $\mathrm{pH}$ value was $8.195 \pm 0.001$ and the initial DIC value was $1969 \pm 13 \mu \mathrm{mol} \mathrm{kg}{ }^{-1}$. The $\mathrm{pH}$ value decreased to $8.079 \pm$ 0.078 and DIC increased to $2000 \pm 62 \mu \mathrm{mol} \mathrm{kg}^{-1}$ when $10 \mu \mathrm{mol} \mathrm{L^{-1 }}$ of SNP was added to the culture media, which strongly inhibited the growth of microalgae. The variations of $\mathrm{pH}$ were less than 0.1 units after the supplement of $0.01,0.1$, and $1.0 \mu \mathrm{mol} \mathrm{L}^{-1}$ of SNP compared with the control. The DIC values are similar when exposed to $0.01,0.1$, and $1.0 \mu \mathrm{mol} \mathrm{L}^{-1}$ of SNP, respectively. The values of $p \mathrm{CO}_{2}$ were less than $25 \mu \mathrm{atm}$ in the algal culture media with the addition of $0.01,0.1$, and $1 \mu \mathrm{mol} \mathrm{L^{-1 }}$ of SNP. However, $p \mathrm{CO}_{2}$ increased to $533 \pm 2 \mu \mathrm{atm}$ when $10 \mu \mathrm{mol} \mathrm{L}^{-1}$ of SNP was added to the culture media. The initial percentage of $\mathrm{HCO}_{3}{ }^{-}, \mathrm{CO}_{3}{ }^{2-}$, and $\mathrm{CO}_{2}$ concentration was $86.1 \%, 13.5 \%$ and $0.4 \%$ respectively. Meanwhile, the percentage of $\mathrm{HCO}_{3}{ }^{-}, \mathrm{CO}_{3}{ }^{2-}$, and $\mathrm{CO}_{2}$ concentration was $91.4 \%, 7.8 \%$, and $0.8 \%$ respectively when 10 $\mu \mathrm{mol} \mathrm{L}{ }^{-1}$ of SNP was added to the culture media. The variation characteristic of $\mathrm{HCO}_{3}{ }^{-}$was similar with that of the DIC considering that $\mathrm{HCO}_{3}{ }^{-}$is the main component of DIC in seawater. However, the percentage of $\mathrm{HCO}_{3}{ }^{-}$in the $S$. costatum culture media with the supplement of $0,0.01,0.1$, and $1.0 \mu \mathrm{mol}$ $\mathrm{L}^{-1}$ of SNP was $48.8 \%, 57.1 \%, 55.8 \%$, and $54.4 \%$, respectively. The corresponding percentage of $\mathrm{CO}_{3}{ }^{2-}$ 
was $51.0 \%, 42.9 \%, 44.2 \%$, and $45.6 \%$, respectively. These observations suggest that the parameters of carbon system could be influenced by the addition of NO.

Table 1

Variations of the parameters of carbonate chemistry in the $S$. costatum culture media after adding different concentrations of SNP solutions, DIC means dissolved inorganic carbon, $p \mathrm{CO}_{2}$ means partial pressure of $\mathrm{CO}_{2}$, TA means total alkalinity.

\begin{tabular}{|c|c|c|c|}
\hline SNP concentration $\left(\mu \mathrm{mol} \mathrm{L}{ }^{-1}\right)$ & $\mathrm{pH}$ & $\begin{array}{l}\text { DIC } \\
\left(\mu \mathrm{mol} \mathrm{kg}{ }^{-1}\right)\end{array}$ & $\begin{array}{l}\text { TA } \\
\left(\mu \mathrm{mol} \mathrm{kg}{ }^{-1}\right)\end{array}$ \\
\hline initial & $8.195 \pm 0.001$ & $1969 \pm 13$ & $2339 \pm 16$ \\
\hline 0 & $9.019 \pm 0.071$ & $1250 \pm 88$ & $2211 \pm 60$ \\
\hline 0.01 & $9.023 \pm 0.062$ & $1232 \pm 66$ & $2040 \pm 32$ \\
\hline 0.1 & $9.047 \pm 0.088$ & $1219 \pm 58$ & $2045 \pm 28$ \\
\hline 1.0 & $9.072 \pm 0.092$ & $1214 \pm 82$ & $2062 \pm 56$ \\
\hline 10.0 & $8.079 \pm 0.078$ & $2000 \pm 62$ & $2208 \pm 49$ \\
\hline
\end{tabular}

\section{Disscussion}

\section{Effects of NO on the growth of the marine microalgae}

The present study employed NO and SNP solutions to investigate the effect of NO on the growth of the marine microalgae. Previous study suggested that the real NO concentrations released by 5,10 , and 100 $\mu \mathrm{mol} \mathrm{L}-1$ of SNP are approximately $6 \times 10^{-9}, 9 \times 10^{-9}$, and $2 \times 10^{-7} \mathrm{~mol} \mathrm{~L}^{-1}$ and with the release time of 4, 5.5 and 7.5 h, respectively (Liu et al. 2010). However, high reactivity of NO reduces its concentration rapidly in the culture media when direct NO solution was added to the media. Therefore, the addition of NO and SNP solutions represented the short- and long-term effects of NO on algae growth, respectively. The most fundamental reason is the effect of the final NO concentration on the growth of microalgae. It is noteworthy that the function of NO in the algae growth is not in such a way that NO first changed into $\mathrm{NO}_{2}$ and then into $\mathrm{NO}_{3}{ }^{-}$or $\mathrm{NO}_{2}{ }^{-}$after it was added into the cultivation medium (Zhang et al. 2005).

The results showed that the growth of algae was promoted when $10^{-9}-10^{-6} \mathrm{~mol} \mathrm{~L}^{-1}$ of NO solutions were added to the algae culture media. That is, the addition of $10^{-6} \mathrm{~mol} \mathrm{~L}^{-1}$ of $\mathrm{NO}$ solution exhibited the optimum stimulatory effect on all the five microalgae. The other concentrations of NO had less influence on the growth of algae. Moreover, different algae had different responses to the same concentration of NO. No significant difference on the effect of NO solution was identified between the food and red tide algae. The present study was in consist with previous study that different phytoplankton has different optimum NO concentration (Zhang et al. 2005). However, food algae and red tide algae showed different response to the same concentration of NO, which was not observed in the present study when different 
concentrations of NO solutions were added to the five microalgae cultures. Such difference might be caused by the different temperature, light irradiance, NO addition type and species of microalgae.

However, a distinct difference in the responses to the SNP solution was revealed between these two types of algae. SNP with the concentration of $100 \mu \mathrm{mol} \mathrm{L}^{-1}$ strongly inhibited the growth of the two food algae. $10 \mu \mathrm{mol} \mathrm{L} \mathrm{L}^{-1}$ of SNP had a similar effect on the growth of the red tide algae, however, a slight promotion effect on the two food algae was observed with the same concentration of SNP. Similar results were found in the experiment with $1 \mu \mathrm{mol} \mathrm{L}{ }^{-1}$ of SNP addition, which promoted the growth of the food algae. Different results were found for the three red tide algae, indicating that the red tide algae were more sensitive to exogenous NO than food algae.

The NO concentration released by $10 \mu \mathrm{mol} \mathrm{L}^{-1}$ of SNP was equivalent to $9 \times 10^{-9} \mathrm{~mol} \mathrm{~L}^{-1}$ of NO for about 5.5 hours (Liu et al. 2010). The short stimulation of $10^{-9} \mathrm{~mol} \mathrm{~L}^{-1}$ caused by the NO solutions had little promotion effect on the growth of the five examined microalgae (Fig. 2). The long stimulation of $10^{-9} \mathrm{~mol} \mathrm{~L}^{-1}$ caused by the $10 \mu \mathrm{mol} \mathrm{L}^{-1}$ of SNP solution promoted the growth of the food algae. However, it greatly inhibited the growth of the red tide algae. Meanwhile, similar results were found when the microalgae were exposed to $1.0 \mu \mathrm{mol} \mathrm{L}^{-1}$ of SNP. Thus, SNP with the concentration of 1.0 and 10 $\mu \mathrm{mol} \mathrm{L} \mathrm{L}^{-1}$ stimulated the growth of food algae while inhibited the growth of red tide algae. In the present study, the real NO concentration, which promoted the growth of red tide algae, was less than $10^{-9} \mathrm{~mol} \mathrm{~L}^{-1}$ given the NO release rules of the SNP and was much lower than the concentration of the direct NO addition. This difference may be related to the duration function of the NO released by SNP in the culture media. SNP with the concentration of 100 and $10 \mu \mathrm{mol} \mathrm{L}^{-1}$ can produce $2 \times 10^{-7}$ and $9 \times 10^{-9} \mathrm{~mol} \mathrm{~L}^{-1}$ NO and maintain 7.5 and 5.5 hours, respectively (Liu et al. 2010). Such concentration of NO produced by SNP can roughly maintain a stable concentration within a certain period, however, the direct addition of NO can rapidly disappear because of its instability. These results indicated that the function of NO on microalgae was closely related to the stimulation time and the concentration range. Moreover, the effect of SNP on the food algae was different from that on the red tide algae.

Previous studies suggested that NO could modulate the cell growth of microalgae by influencing the activity of the enzymes (Lehner et al. 2009). Exogenous NO increased photosynthesis rate of $P$. tricornutum, especially under high light environment, which could be explained that NO protected cell structure from high light damage (Wang et al. 2013). Moreover, Nagase et al. (2001) found that little NO was oxidized in the medium before its uptake by algal cells and NO mostly permeated directly into the cells by diffusion. Therefore, NO can be considered as a signaling molecule in marine microalgae as found in plant.

\section{Physiological functions of NO}

NO was once regarded as a poisonous air pollutant, nowadays it is mostly considered as a signaling hormone in many physiological processes in animals and plants. It is a key signaling molecule that controls plant growth and development, however, when concentrations of NO are too high, it is toxic to 
cells (Beligni and Lamattina, 1999a, 1999b). A relatively lower concentration of NO enhances the photochemical efficiency, increases the net photosynthesis and ameliorates the stress effects on chloroplasts. Misra et al. (2004) proved that NO could act as a regulator of photosynthetic electron transport and regulate the activity of the photosynthetic electron transport either by modifications of the oxygen evolving complex or by activation of the cyclic electron transport around PSII.

The protective mechanism of NO to counteract the abiotic and biotic stress including heavy metal, salinity, UV, herbicide might be associated with the ability of scavenging reactive oxygen species (ROS). The role of NO was achieved by up-regulating the activity of antioxidant enzymes such as Superoxide Dismutase (SOD), guaiacol peroxidase, and glutathione reductase (Mackerness et al. 2001; Uhida et al. 2002; Kopyra and Gwóźdź 2003; Shi et al. 2005; Qian et al. 2009).

The decomposition of SNP yields $\mathrm{NO}$ and $\mathrm{FeC}_{5} \mathrm{~N}_{6}$, the latter of which decomposes to cyanide $(\mathrm{CN})$ and Fe. Lehner et al. (2009) clearly showed that the changes induced by SNP can be ascribed to NO action and not to a release of $\mathrm{CN}$. NO could inhibit the activities of enzymes involved in the secretory pathway, such as Glyceraldehyde-3-phosphate dehydrogenase via S-nitrosylation of the cysteine residue and, consequently, modulates cell growth of green alga M. denticulata (Lehner et al. 2009). Until now, the effect of NO on the marine phytoplankton is still unclear. However, more information revealed that NO acted as molecular messenger as observed in plants (Kumar et al. 2015).

\section{Inorganic carbon parameters in marine microalgae culture media}

Biological photosynthesis can absorb $\mathrm{CO}_{2}$ in seawater, thereby resulting in increased seawater $\mathrm{pH}$ and decreased DIC and $p \mathrm{CO}_{2}$. Note that the absorption of $\mathrm{CO}_{2}$ of the marine microalgae was underestimated because of the low $p \mathrm{CO}_{2}$ during the incubation period. The concentrations of $\mathrm{HCO}_{3}{ }^{-}$decreased significantly in the cultures of $S$. costatum when supplemented with $0.01-1.0 \mu \mathrm{mol} \mathrm{L}^{-1}$ of SNP. A slight increase of DIC value was observed in the culture of $10 \mu \mathrm{mol} \mathrm{L}^{-1}$ of SNP, which was consistent with the growth of $S$. costatum. These results suggested that no carbon was consumed, in contrast, $\mathrm{CO}_{2}$ may be absorbed by the culture media or $S$. costatum released certain concentration of inorganic carbon to the culture media leading to a rise of DIC. Despite of slight increase in the cell density in the S. costatum culture after the addition of $0.1 \mu \mathrm{mol} \mathrm{L}{ }^{-1}$ of SNP, carbon parameters showed no significant difference in comparison with the control group, suggesting there may exist a time lag for the carbon parameter variations.

Some researchers have suggested that $\mathrm{NO}$ is associated with the photosynthesis process. The fumigation of NO immediately reduces the rate of photosynthesis in plants (Hill and Bennett 1970; Caporn 1989). Yamasaki (2000) found that excessive $\mathrm{NO}$ directly inhibits $\mathrm{CO}_{2}$ assimilation and electron flow in the mitochondrial inner membrane of photosynthesizing organisms. Our examination of the parameters of the carbonate chemistry demonstrated that $\mathrm{CO}_{2}$ assimilation was affected by different concentrations of $\mathrm{NO}$, high concentrations of $\mathrm{NO}\left(100 \mu \mathrm{mol} \mathrm{L}^{-1}\right.$ of SNP) restrained $\mathrm{CO}_{2}$ assimilation, 
whereas low concentrations of $\mathrm{NO}\left(0.01-1.0 \mu \mathrm{mol} \mathrm{L}^{-1}\right.$ of SNP) promoted $\mathrm{CO}_{2}$ assimilation, which was consistent with the observations in plants.

\section{Conclusions}

The experimental results of adding NO and SNP solutions into the marine microalgae culture media showed that exogenous NO had different effects on the growth of five marine microalgae. The direct NO and SNP additions showed different patterns of growth for the three red tide algae, which can be explained as that SNP results in a long NO action on algae and exhibits different behaviors. The two food algae and three red tide algae showed different responses to the same concentration of NO. Moreover, the red tide algae were more sensitive to SNP additions than the food algae. These results might be caused by the species-specific characteristics of the microalgae.

NO with the concentration of $1.4 \times 10^{-6} \mathrm{~mol} \mathrm{~L}^{-1}$ had the optimum stimulatory effect on the growth of microalgae. While the other concentrations of NO showed little effect. SNP solution with the concentration of $100 \mu \mathrm{mol} \mathrm{L}^{-1}$ inhibited the growth of the two food algae, however, $10 \mu \mathrm{mol} \mathrm{L}^{-1} \mathrm{SNP}$ solution additions to the three red tide algae inhibited the growth greatly. Low concentrations of SNP ( 0.1 $\mu \mathrm{mol} \mathrm{L}-1$ for the two food algae and $0.01 \mu \mathrm{mol} \mathrm{L}^{-1}$ for the red tide algae) promoted the growth of microalgae. The parameters of carbon system could be influenced by NO addition, suggesting that NO could regulate $\mathrm{CO}_{2}$ assimilation of algae. However, the regulation function of $\mathrm{NO}$ on the photosynthesis of marine microalgae and the function mechanism need further study.

\section{Declarations}

Funding This research was supported by the National Natural Science Foundation of China (grant nos. 41676065 and 40706040) and the National Key Research and Development Program of China (grant no. 2016YFA0601301).

Conflicts of Interest There are no conflicts of interest for this submission.

Ethics approval The authors conform that the work described was original research that has not been published previously, and not under consideration for publication elsewhere. Citations to appropriate and relevant literature are used throughout.

Data availability statement The datasets of the current study are available from the corresponding author on reasonable request.

Author contribution All authors contributed to the study conception and design. Material preparation, data collection and analysis were performed by Zhao Min. The first draft of the manuscript was written by Li Peifeng and all authors commented on previous versions of the manuscript. All authors read and approved the final manuscript. 


\section{References}

1. Anifowose AJ, Sakugawa H (2017) Determination of daytime flux of nitric oxide Radical (NO) at an inland sea-atmospheric boundary in Japan. J Aquat Pollut Toxicol 1:1-6. https://doi.org/10.21767/2581-804X.100010

2. Beligni MV, Lamattina L (1999a) Nitric oxide protects against cellular damage produced by methylviologen herbicides in potato plants. Nitric Oxide 3:199-208. https://doi.org/10.1006 /niox.1999.0222

3. Beligni MV, Lamattina L (1999b) Is nitric oxide toxic or protective? Trends Plant Sci 4:299 - 300 . https://doi.org/10.1016/S1360-1385(99)01451-X

4. Cai WJ, Wang YC (1998) The chemistry, fluxes, and sources of carbon dioxide in the estuarine waters of the Satilla and Altamaha Rivers, Georgia. Limnol Oceanogr 43(4):657-668.

https://doi.org/10.4319/lo.1998.43.4.0657

5. Caporn SJM (1989) The effects of oxides of nitrogen and carbon dioxide enrichment on photosynthesis and growth of lettuce (Lactuca sativa L.). New Phytol 111:473 - 481. https://doi.org/10.1111/j.1469-813.1989. tb00710. x

6. Chen $\mathrm{K}$, Feng $\mathrm{H}$, Zhang $\mathrm{M}$, Wang $X$ (2003) Nitric oxide alleviated oxidative damage in the green algae Chlorella Pyrenoisoda caused by UV-B radiation. Folia Microbiol 48:389-393. https://doi.org/10.1007/BF02931372

7. Chi Z, O'Fallon JV, Chen S (2011) Bicarbonate produced from carbon capture for algae culture. Trends Biotechnol 29:537 - 541. https://doi.org/10.1016/j.tibtech.2011.06.006

8. Domingos P, Prado AM, Wong A, Gehring C, Feijo JA (2015) 0) Nitric Oxide: A Multitasked Signaling Gas in Plants. Mol Plant 8:506 - 520. https://doi.org/10.1016/j.tibtech.2011. 06.006

9. Dickson AG, Millero FJA (1987) Comparison of the equilibrium constants for the dissociation of carbonic acid in seawater media. Deep-Sea Res 34:1733-1743. https://doi.org/10.1016/01980149(87)90021-5

10. Dickson AG (1990) Standard potential of the reaction: $\mathrm{AgCl}(\mathrm{s})+1 / 2 \mathrm{H}_{2}(\mathrm{~g})=\mathrm{Ag}(\mathrm{s})+\mathrm{HCl}(\mathrm{aq})$, and and the standard acidity constant of the ion $\mathrm{HSO}_{4}{ }^{-}$in synthetic sea water from 273.15 to $318.15 \mathrm{~K}$. J Chem Thermodyn 2:113-127. https://doi.org/10.1016/0021- 9614(90)90074-Z

11. Feng WH, Liu CY, Yang GP, Li PF (2011) The effect of exogenous NO and copper onthe antioxidant systems of marine algae. Periodical Ocean University of China 4:69-74 (in Chinese with English abstract)

12. Floryszak-Wieczorek J, Milczarek G, Arasimowicz M, Ciszewski A (2006) Do nitric oxide donors mimic endogenous NO-relatedresponse in plants? Planta 224:1363 - 1372. https://doi.org/10.1007/s00425-006-0321-1

13. Grasshoff K, Kremling K, Ehrhardt M (1999) Methods of Seawater Analysis. Wiley, New York, pp 149158. https://doi.org/10.1002/9783527613984 
14. Guillard RRL (1975) Culture of Phytoplankton for Feeding Marine Invertebrates. In: Smith WL, Chanley MH (eds) Culture of Marine Animals. Plenum Press, New York, pp 26-60. https://doi.org/10.1007/978-1-4615-8714-9_3

15. Gupta KJ, Igamberdiev AU, Manjunatha G, Segu S, Moran JF, Neelawarne B, Bauwe H, Kaiser WM (2011) The emerging roles of nitric oxide (NO) in plant mitochondria. Plant Sci 181:520-526. https://doi.org/10.1016/j.plantsci.2011.03.018

16. Hill AC, Bennett JH (1970) Inhibition of apparent photosynthesis by nitrogen oxides. Atmos Environ 4:341 - 348. https://doi.org/10.1016/0004-6981(70)90078-8

17. Hu YB, Liu CY, Yang GP, Zhang HH (2015) The response of the carbonate system to a green algal bloom during the post-bloom period in the southern Yellow Sea. Cont Shelf Res 94:1-7. https://doi.org/10.1016/j.csr.2014.12.006

18. Kim D, Kang YS, Yoon L, Yamaguchi K, Matsuoka K, Lee KW, Choi KS, Oda T (2008) Detection of nitric oxide (NO) in marine phytoplankters. J Biosci Bioeng 105:414-417. https://doi.org/10.1263/jbb.105.414

19. Kim D, Yama G, Oda T (2006) Nitric oxide synthase-like enzyme mediated nitric oxide generation by harmful red tide phytoplankton, Chattonella marina. J Plankton Res 28:613-620. https://doi.org/10.1093/plankt/fbi145

20. Kopyra M, Gwóźdź EA (2003) Nitric oxide stimulates seed germination and counteracts the inhibitory effect of heavy metals and salinity on root growth of Lupinus luteus. Plant Physiol Bioch 41:10111017. https://doi.org/10.1016/j.plaphy.2003.09.003

21. Kumar A, Castellano I, Patti FP, Palumbo A, Buia MC (2015) Nitric oxide in marine photosynthetic organisms. Nitric Oxide 47:34 - 37. https://doi.org/10.1016/j.niox.2015.03.001

22. Lantoine F, Brunet A, Bedioui F, Devynck J, Devynck MA (1995) Direct measurement of nitric oxide production in platelets: relationship with cytosolic $\mathrm{Ca}^{2+}$ concentration. Biochem Bioph Res Co 215:842 - 848. https://doi.org/10.1006/bbrc. 1995.2540

23. Lehner C, Kerschbaum HH, Lütz-Meindl U (2009) Nitric oxide suppresses growth and development in the unicellular green alga Micrasterias denticulata. J Plant Physiol 2:117-127. https://doi.org/10.1016/j.jplph.2008.02.012

24. Leshem YY, Wills RH, Ku VV-V (1998) Evidence for the function of the free radical gas-nitric oxide (NO) - as an endogenous maturation and senescence regulating factor in higher plants. Plant Physiol Biochem 36(99):825-833. https://doi.org/10.1016/S0981-9428 80020-5

25. Li L, Moore PK (2007) An overview of the biological significance of endogenous gases: new roles for old molecules. Biochem Soc T 35:1138-1141. https://doi.org/10.1042/BST0351138

26. Li PF, Liu CY, Liu HH, Zhang Q, Wang L (2013) Protective function of nitric oxide on marine phytoplankton under abiotic stresses. Nitric Oxide 33(9):88-96. https://doi.org /10.1016/j.niox.2013.06.007

27. Lipton SA, Chol YB, Pan ZH, Lel SZ, Chen H-SV, Sucher NJ, Losclzo J, Singel DJ, Stalmer JS (1993) A redox-based mechanism for the neuroprotective and effects of nitric oxide and related nitroso- 
compounds. Nature 364:626-632. https://doi.org/10.1038/364626a0

28. Liu CY, Fang S, Zhao M, Bai XJ, Han Y, Li PF (2010) Fluorescence Dynamic Monitoring of Nitric Oxide Release Process Following Administration of Sodium Nitroprusside and Its Effect on the Growth of Microalga. Asian Journal of Ecotoxicology 5:362-367 (in Chinese with English abstract)

29. Liu CY, Gao CX, Zhang HB, Chen S, Deng P, Yue XA, Guo XY (2014a) Production of dimethylsulfide and acrylic acid from dimethylsulfoniopropionate during growth of three marine microalgae. Chin $\mathrm{J}$ Oceanol Limn 6:1270-1279. http://dx.doi.org/10.1007/s00343-015-4029-6

30. Liu CY, Kieber DJ, Yang GP, Xue C, Liu WLL HH (2014b) Evidence for the mutual effects of dimethyl sulfoniopropionate and nitric oxide during the growth of marine microalgae. Nitric Oxide 42:54-61. http://dx.doi.org/10.1016/j.niox.2014.09.003

31. Liu CY, Li PF, Ren CY, Huang HW, Zhang ZB (2008) Effects of nitric oxide and copper on marine algae growth. Journal of Harbin Institute Technology 40:812-817 (in Chinese with English abstract)

32. Lushchak VI (2011) Adaptive response to oxidative stress: Bacteria, fungi, plants and animals. Comp Biochem Phys C 153(2):175-190. https://doi.org/10.1016/j.cbpc.2010.10.004

33. Mackerness SAH, John CF, Jordan B, Thomas B (2001) Early signaling components in ultraviolet-B responses: distinct roles for different reactive oxygen species and nitric oxide. FEBS Lett 489:237242. https://doi.org/10.1016/S0014-5793(01)02103-2

34. Mallick N, Mohn FH, Soeder CJ (2000) Evidence sporting nitrite-dependent NO release by the green microalga Scenedesmus Obliquus. Plant Physiol 157:40-46. https://doi.org/ 10.1016/S01761617(00)80133-9

35. Mallick N, Rai LC, Mohn FH, Soeder CJ (1999) Studies on nitric oxide (NO) formation by green alga Scenedesmus Obliquua and the diazotrophic cyanobacterium Anabaena doliolum. Chemosphere 39:1601-1610. https://doi.org/10.1016/S0045-6535(99)00058-2

36. Martens-Habbena W, Qin W, Horak REA, Urakawa H, Schauer AJ, Moffett JW, Armbrustb EV, Ingalls AE, Devol AH, Stahl DA (2015) The production of nitric oxide by marine ammonia-oxidizing archaea and inhibition of archaeal ammonia oxidation by a nitric oxide scavenger. Environ Microbiol 17(2):261 -261 2274. https://doi.org/10.1111/1462-2920. 12677

37. Mehrbach C, Culberson CH, Hawley JE, Pytkowicx RM (1973) Measurement of the apparent dissociation constants of carbonic acid in the seawater at atmospheric pressure. Limnol Oceanogr 18:897-907. https://doi.org/10.4319/lo.1973.18.6.0897

38. Mittler R, Vanderauwera S, Gollery M, Breusegem FV (2004) Reactive oxygen gene network of plants. T Plant Sci 9:490-498. https://doi.org/10.1016/j.tplants.2004.08.009

39. Misra AN, Vladkova R, Singh R, Misr M, Dobrikova AG, Apostolova EL (2014) Action and target sites of nitric oxide in chloroplasts. Nitric Oxide 39:35-45. https://doi.org/10.1016/j. niox.2014.04.003

40. Nagase H, Yoshihara K, Eguchi K, Okamoto Y, Murasaki S, Yamashita R, Hirata K, Miyamoto K (2001) Uptake pathway and continuous removal of nitric oxide from flue gas using microalgae. Biochem Eng J 7:241-246. https://doi.org/10.1016/S1369-703X(00)00122-4 
41. Olasehinde EF, Takeda K, Sakugawa H (2009) Development of an Analytical Method for Nitric Oxide Radical Determination in Natural Waters. Anal Chem 81(16):6843-6850. https://doi.org/10.1021/ac901128y

42. Olasehinde EF, Takeda K, Sakugawa H (2010) Photochemical production and consumption mechanisms of nitric oxide in seawater. Environ Sci Technol 44:8403-8408. https://doi.org/10.1021/es101426x

43. Pierrot DE, Lewis E, Wallace DWR (2006) MS Excel program developed for $\mathrm{CO}_{2}$ system calculations. Carbon Dioxide Information Analysis Center, Oak Ridge National Laboratory, US Department of Energy. Available from http://cdiac.ornl.gov/ftp/co2sys (Accessed 25 November 2019)

44. Planchet E, Gupta KJ, Sonoda M, Kaiser WM (2005) Nitric oxide emission from tobacco leaves and cell suspensions: rate limiting factors and evidence for the involvement of mitochondrial electron transport. Plant J Cell Mol Biol 41(5):732-743. https://doi.org/10.1111/j.1365-313x.2005.02335.x

45. Qian HF, Chen W, Li JJ, Wang J, Zhou Z, Liu WP, Fu ZW (2009) The effect of exogenous nitric oxide on alleviating herbicide damage in Chlorella vulgaris. Aquatic Toxicol 92:250-257. https://doi.org/10.1016/j.aquatox.2009.02.008

46. Sakihama Y, Nakamura S, Yamasaki H (2002) Nitric oxide production mediated by nitrate reductase in the green alga Chlamydomonas reinhardtii: an alternative NO production pathway in photosynthetic organism. Plant Cell Physiol 43:290-297. https://doi.org/10.1093/pcp /pcf034

47. Shi SY, Wang G, Wang YD, Zhang LG, Zhang LX (2005) Protective effect of nitric oxide against oxidative stress under ultraviolet-B radiation. Nitric Oxide 13:1-9. https://doi.org/10.1016/j.niox.2005.04.006

48. Singh AK, Sharma L, Mallick N (2004) Antioxidative role of nitric oxide on copper toxicity to a chlorophycean alga. Chlorella Ecotox Environ Safe 59:223-227. https://doi.org/10.1016/j.ecoenv.2003.10.009

49. Tang X, Chen J, Wang WH, Liu TW, Zhang J, Gao Y, Pei ZM, Zheng HL (2011) The changes of nitric oxide production during the growth of Microcystis aerugrinosa. Environ Pollut 159: $3784-3792$. https://doi.org/10.1016/j.envpol.2011.06.042

50. Tian Y, Yang GP, Liu CY, Li PF, Bange HW (2020) Photoproduction of nitric oxide in seawater. Ocean Sci 16:135-148. https://doi.org/10.5194/os-16-135-2020

51. Tian Y, Wang K-K, Yang G-P, Li P-F, Liu C-Y, Ingeniero RCO, Bange HW (2021) Continuous Chemiluminescence Measurements of Dissolved Nitric Oxide $(\mathrm{NO})$ and Nitrogen Dioxide $\left(\mathrm{NO}_{2}\right)$ in the Ocean Surface Layer of the East China Sea. Environ Sci Technol 55:3668-3675

52. Tischner R, Planchet E, Kaiser WM (2004) Mitochondrial electron transport as a source for nitric oxide in the unicellular green alga Chlorella sorokiniana. FEBS Lett 576:151-155. https://doi.org/10.1016/j.febslet.2004.09.004

53. Uhida A, Jagendorf AT, Hibino T, Takabe T (2002) Effects of hydrogen peroxide and nitric oxide on both salt and heat stress tolerance in rice. Plant Sci 163(02):515-523. https://doi.org/10.1016/S0168-9452 00159-0 
54. Wang X, Xu Y, Zhong Y, Jing B (2013) P30: effects of nitric oxide on photosynthesis rate of phaeodactylum tricornutum. Nitric Oxide 31: S25 - S26. https://doi.org/10.1016/j.niox. 2013.02.032

55. Wendehenne D, Pugin A, Klessig D, Durner J (2001) Nitric oxide: comparative synthesis and signaling in animal and plant cells. T Plant Sci 6:177-183. https://doi.org/10.1016/S1360-1385(01)01893-3

56. Wilhelm C, Büchel C, Fisahn J, Goss R, Jakob T, Laroche J, Lavaud J, Lohr M, Riebesell U, Stehfest K, Valentin K, Kroth PG (2006) The regulation of carbon and nutrient assimilation in diatoms is significantly different from green algae. Protist 2:91-124. https://doi.org/10.1016/j.protis.2006.02.003

57. Wink DA, Mitchell JB (1998) Chemical biology of nitric oxide: insights into regulatory, cytotoxic and cytoprotective mechanisms of nitric oxide. Free Radical Biol Med 25:434-456. https://doi.org/10.1016/S0891-5849(98)00092-6

58. Xiao Y, Liu Y, Wang G (2012) Involvement of nitric oxide in the mechanism of biochemical alterations induced by simulated microgravity in Microcystis aeruginosa. Adv Space Res 49:850-858. https://doi.org/10.1016/j.asr.2011.11.003

59. Xing L, Zhang ZB, Liu CY, Wu ZZ, Lin C (2005) Amperometric detection of nitric oxide with microsensor in the medium of seawater and its applications. Sensors 5: 537-545. https://doi.org/10. 3390/s5120537

60. Yamasaki H (2000) Nitrite-dependent nitric oxide production pathway: implications for involvement of active nitrogen species in photoinhibition in vivo. Philos Trans R Soc Lond 355:1477-1488. https://doi.org/10.1098/rstb.2000.0708

61. Zafiriou OC, McFarland M (1981) Nitric oxide from nitrite photolysis in the central equatorial Pacific. J Geophys Res 86:3173-3182. https://doi.org/10.1029/ JC086iC04p03173

62. Zafiriou OC, True MB (1979) Nitrite photolysis in seawater by sunlight. Mar Chem 8:9-32. https://doi.org/10.1016/0304-4203(79)90029-X

63. Zhang ZB, Lin C, Liu C, Xing L, Wu ZZ, Sun F (2005) Study on patterns and chemical features of NO effect on marine phytoplankton growth. Sci China 48(4):376-384. https://doi.org/10.1360/03yb0166

64. Zhang ZB, Liu CY, Wu ZZ, Xing L, Li PF (2006a) Detection of nitric oxide in culture media and studies on nitric oxide formation by marine microalgae. Med Sci Monitor 12:75-85

65. Zhang ZB, Wu ZZ, Liu CY, Xing L (2006b) The study on the effect of NO on the growth of Chaetoceros curvisetus. Chin J Oceanol Limnol 24:413-420. https://doi.org/10.1007/BF02842858

66. Zhang ZB, Xing L, Wu ZZ, Liu CY, Lin C, Liu LS (2006c) Discovery of nitric oxide in marine ecological system and the chemical characteristics of nitric oxide. Sci China 5:475-480. https://doi.org/10.1007/s11426-006-2017-6

67. Zhang ZB, Xing L, Jiang LQ, Wang YC, Ren CY, Cai WJ (2003) The electrochemical determination of nitric oxide in seawater media with microelectrodes. Sensors 3:304-313. https://doi.org/10.3390/s30800304 
Figures

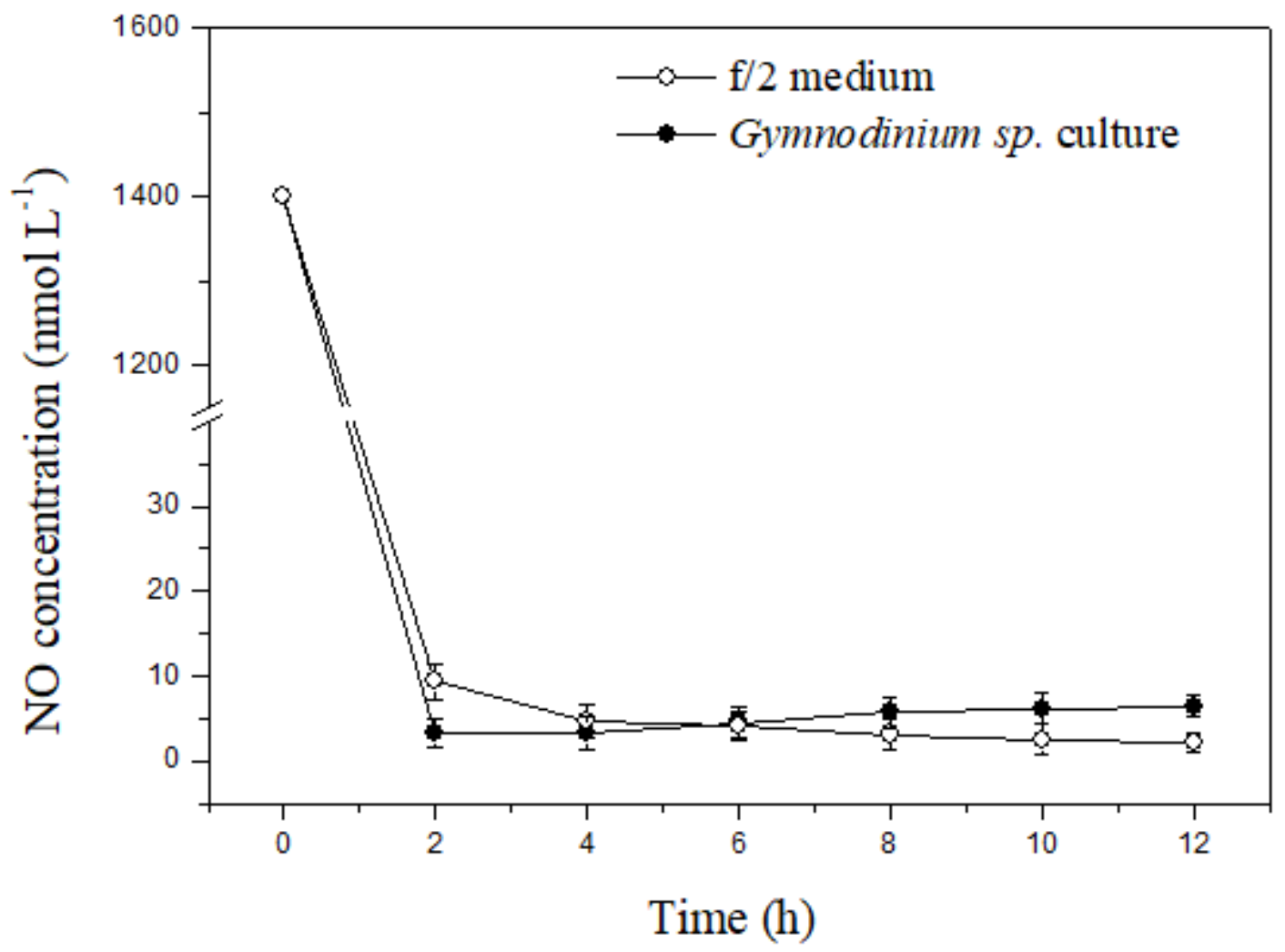

Figure 1

The variations of NO concentrations in the $\mathrm{f} / 2$ medium and Gymnodinium sp. culture media after adding $1.4 \times 10-6 \mathrm{~mol} \mathrm{~L}-1$ of $\mathrm{NO}$ 

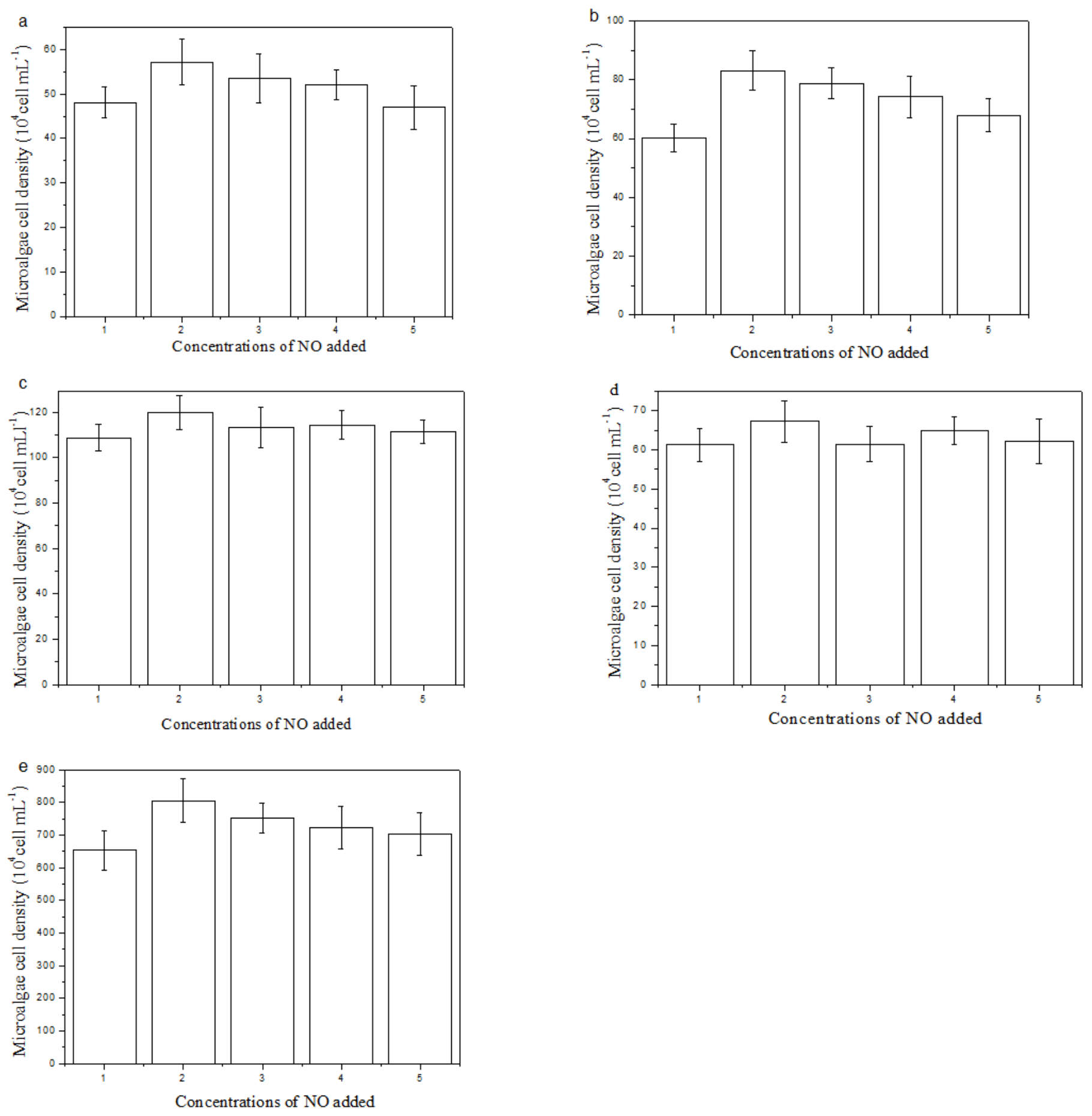

Figure 2

Effects of NO solutions on the growth of five microalgae. (a) P. helgolandica var. tsingtaoensis, (b) P. subcordiformis, (c) S. costatum, (d) Gymnodinium sp., and (e) P. donghaiense. (1: 0 (the control); 2: $1.4 \times$ 10-6 mol L-1; 3: $1.4 \times 10-7 \mathrm{~mol} \mathrm{~L}-1 ; 4: 1.4 \times 10-8 \mathrm{~mol} \mathrm{~L}-1 ; 5: 1.4 \times 10-9 \mathrm{~mol} \mathrm{~L}-1$. The initial cell densities were $2.25 \times 104,5.67 \times 104,12.00 \times 104,2.80 \times 104$, and $56.00 \times 104$ cell mL-1, respectively.) 

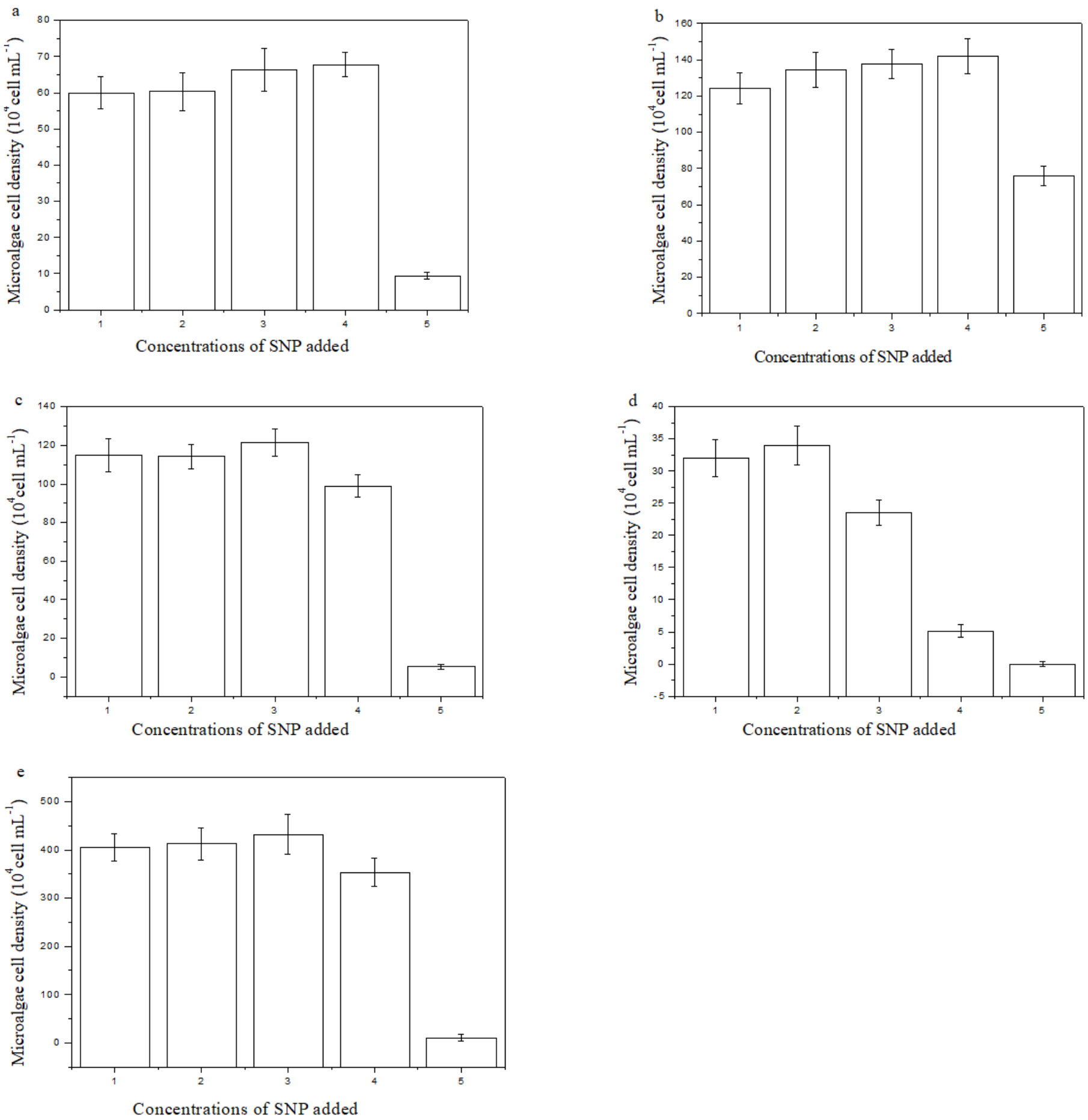

Figure 3

Effects of SNP solutions on the growth of five microalgae. (a) P. helgolandica var. tsingtaoensis, (b) P. subcordiformis, (c) S. costatum, (d) Gymnodinium sp., and (e) P. donghaiense. (For a and b, 1: 0 (the control)); 2: $0.1 \mu \mathrm{mol} L-1 ; 3: 1.0 \mu \mathrm{mol} \mathrm{L}-1 ; 4: 10 \mu \mathrm{mol} \mathrm{L}-1 ; 5: 100 \mu \mathrm{mol} L-1 ;$ For $\mathrm{c}, \mathrm{d}$ and e, $1: 0$ (the control)); 2: $0.01 \mu \mathrm{mol} \mathrm{L-1;} \mathrm{3:} 0.1 \mu \mathrm{mol} \mathrm{L}-1 ; 4: 1 \mu \mathrm{mol} \mathrm{L}-1 ; 5: 10 \mu \mathrm{mol} \mathrm{L}-1$. The initial cell densities were $1.98 \times 104,6.08 \times 104,18.40 \times 104,1.23 \times 104$, and $47.86 \times 104$ cell $\mathrm{mL}-1$, respectively.) 